\title{
Review of China-Pakistan Economic Corridor and Subsequent Development and Economic Growth
}

\author{
Longbao Wei \\ Department of Agricultural Economics and Management \\ Zhejiang University \\ Hangzhou, China
}

\author{
Faiza Manzoor* \\ Department of Agricultural Economics and Management \\ Zhejiang University \\ Hangzhou, China \\ faiza1885@yahoo.com
}

\author{
Abdul Latif \\ Department of Management Sciences \\ Abbottabad University of Science and Technology \\ Khyber Pakhtunkhwa, Pakistan
}

\begin{abstract}
The Belt and Road initiative is a regional connectivity approach that consists of 68 countries and six economic corridors, among them China-Pakistan Economic Corridor is a mega project that builds a strategic framework for the bilateral practical cooperation and is a flagship project for the connectivity between China and its neighboring countries. This plan is likely to provide a powerful stimulus to the national and international economy. China-Pakistan Economic Corridor is equally important for China as it links China's western area and will serve as a shortest probable route to Central Asia and other regions. It is massive bilateral project to improve infrastructure within Pakistan for better trade with China and to further integrate the countries of the region. It is a set-up of roads, railways and dry ports from Gwadar Port to Kashgar aiming mutual cooperation and development of China and Pakistan. China is giving its extra attention to improve the amenities at Gwadar port for increasing its existing competencies thus permitting both the countries to equally reap its maximum benefits. The successful achievement of this venture would also persuade additional investment from neighbor countries. Being an ongoing project, with its soft and smooth accomplishment the inhabitants from both the countries are expected to gain substantial benefits through the China-Pakistan Economic Corridor.
\end{abstract}

Keywords-Belt and Road initiative; China-Pakistan Economic Corridor; Economic growth; Development.

\section{INTRODUCTION}

One Belt one Road, (OBOR) also known as the Belt and Road Initiative (BRI) is a project initiated by the Chinese President $\mathrm{Xi}$ Jinping. Its objective is to build trade routes between China and the countries in Central Asia, Europe, and Indo-Pacific littoral countries (Littoral countries situated on the shore of Indian and the Pacific Ocean) [1]. BRI is a network of roads, railways, oil pipelines, power grids, ports and other infrastructural projects meant to connect China to the world (Fig. 1). It was announced in the year 2013 with an objective to rejuvenate the ancient trade routes connecting Asia to Europe (Known as the Silk Road or the Silk Route) [2]. The BRI initiative has been bifurcated into two parts: The 'Belt' refers to the 'Silk Road Economic Belt 'which is landbased. It will connect China with Central Asia, Eastern, and Western Europe. The 'Road' refers to the '21st Century Maritime Silk Road' which is sea-based. It will connect China to South-East Asia, Africa, and Central Asia [3]. Six economic corridors and one maritime route have been proposed under the BRI: New Eurasian Land Bridge. (Connect Western China to Western Russia), China - Mongolia - Russia Corridor (North China to Eastern Russia via Mongolia), China Central Asia - West Asia Corridor (Western China to Turkey via Central and West Asia, China - Indochina Peninsula Corridor (Southern China to Singapore via Indo-China) China - Pakistan Corridor (South Western China to and through Pakistan), Bangladesh - China - India - Myanmar Corridor (Southern China to India via Bangladesh and Myanmar), Maritime Silk Road connecting Coastal China to the Mediterranean via Singapore-Malaysia, the Indian Ocean, the Arabian Sea and the Strait of Hormuz [4].

BRI is an ambitious project and it encompasses almost 68 countries. China has planned around $\$ 1$ trillion of investment in various infrastructure projects by providing loans to the countries involved at a low cost [5]. China's BRI initiative is a rather ambitious one, towards grooming Information and Communication Technology and economic development. BRI initiative proposes significant potential in several fields including information technology, economic, political, cultural and strategic fields, not only for China but for the whole of Asia and Asia-Pacific. This initiative may help in developing the technological trade and economic cooperation in the Asian region [6]. 


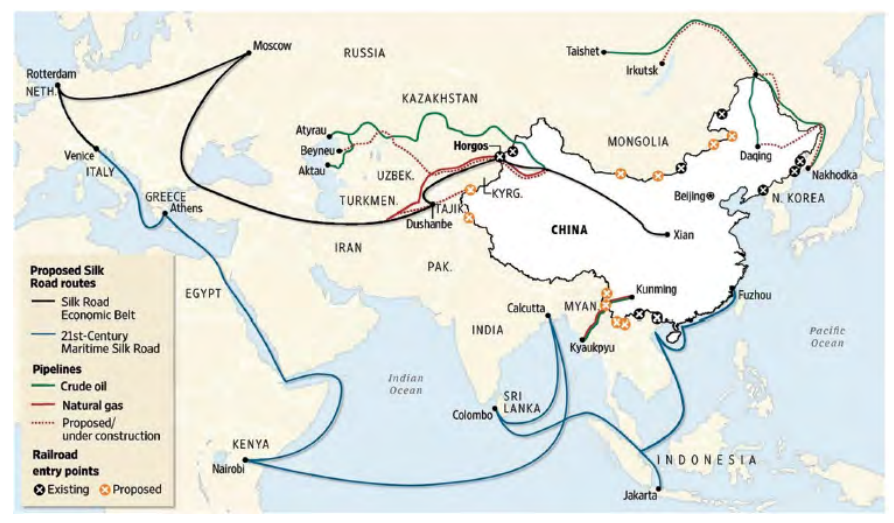

Fig. 1. Source: stability/NTA4MQ=.

As a part of BRI, China develops CPEC. It is expected to connect Kashgar in (Xinjiang province) China's far west with the Port of Gwadar (Baluchistan province) through the network of, railways, highways and pipelines [7]. The aim of CPEC is destined to boost the economic growth and development in both countries through various projects. The important projects developed by Pakistan and China through active collaboration, include transportation infrastructure, energy power plants, industrial complexes and the Gwadar port area [8]. This paper is a review of CPEC and via this project economic growth and development.

\section{BACKGROUND OF CPEC}

Plans for a corridor stretching from the Chinese border to Pakistan's deepwater ports on the Arabian Sea date back to the 1950s, and motivated construction of the Karakoram Highway beginning in 1959 [9].Chinese interest in Pakistan's deepwater harbor at Gwadar had been rekindled by 1998 and in 2002 China began construction at Gwadar port which was completed in 2006 [10].

The current form of the project was first proposed by the President and Prime Minister of Pakistan invited heads of all the political parties to a luncheon in honor of the Chinese Premier Li Keqiang on 22nd May 2013 [11]. In November 2014, the Chinese government announced its intention to finance Chinese companies as part of its $\$ 45.6$ billion energy and infrastructure projects in Pakistan as part of CPEC [12].

During the state visit of Xi Jinping to Pakistan in April 2015, he wrote in an open editorial stating: "This will be my first trip to Pakistan, but I feel as if I am going to visit the home of my own brother." On 20th April 2015, Pakistan and China signed an agreement to commence work on the $\$ 46$ billion agreement, which is roughly $20 \%$ of Pakistan's annual GDP, With approximately $\$ 28$ billion worth of fast-tracked "Early Harvest" projects to be developed by the end of 2018 [13].

\section{Subsequent DeVElopment Under CPEC}

An international trade route in Pakistan just started up by a Chinese vessel transferring goods to the Middle East and Africa. The economic route is being developed by China in Pakistan is likely to make a huge amount of economic advantages for both countries [14]. CPEC is one of the most important developments of the 'BRI' projects started by China that aims to link China with Europe and Africa making the most important country in world economic affairs [15]. CPEC connects north-western region of Xinjiang of China with Pakistan's Port of Gwadar on the Arabian Sea via a network of Highways, Rail system (2,500 km road and rail Route) and Pipelines to transport oil, gas and other resources (Fig. 2). The investment of $\$ 46$ billion by China is not limited to roads and rail link but also on other infrastructure projects which include the development of Gwadar port, a new international airport in Gwadar, and several energy projects that will add around 10,400 MW in National Power Grid [16].

\section{A. Benefits to China}

CPEC brings unlimited benefits for China as when the structure of the corridor will be completed; it will expand to more trade routes between China, the Middle East, Europe and Africa as well as its neighbouring south Asian countries. As China is the biggest energy consumer so oil transferring through pipelines from Pakistan would reduce the transit time for China [17]. The Middle East exports crude oil to China and this is being moved by Sea covering 10,000 miles to reach China. After completing the CPEC Project it will be reduced to $2500 \mathrm{KM}$ through Gwadar Port to Kashgar [16]. Gas and oil supply to china will become more cheap and fast from Middle East countries to China. CPEC will also provide China unparalleled reach to energy-rich markets of Central Asia and Afghanistan. These regions are collectively perceived as the next big things in terms of energy and natural resources [18]. China is utilizing this for securing its energy needs as well as having an influence on the future energy sources as now held by the US over the gulf countries. China will make commercial and economic link stronger and durable with south Asian countries [17]. China will be connected with Iran through Quetta-Zahidan railway link.

CPEC will also give economic benefits to flow to less developed regions of western China containing Muslims majority city Xinjiang and hopes to eliminate the unrest there. CPEC will provide China an additional Sea Port opening to the world and the capability to blockade the sea supplies to any future opponents by having a port at Gwadar [19].

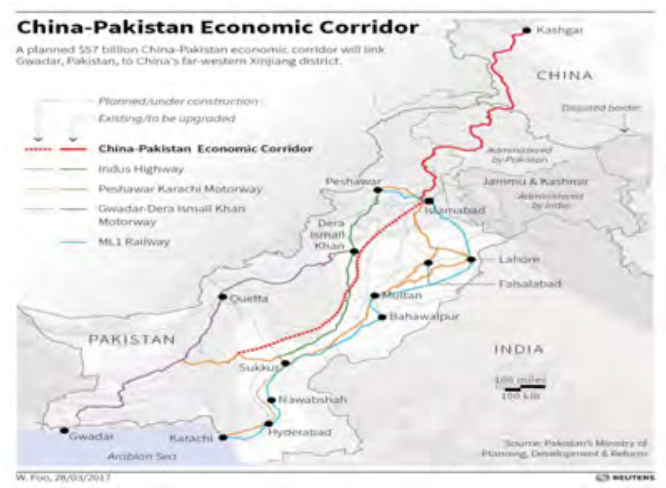

Fig. 2. Source: cpec.gov.pk. 


\section{B. Benefits to Pakistan}

Pakistan today is starving for foreign investment in the country because of the security situation. Foreign companies may set up distribution networks to fulfill domestic demand after completion of Gwadar Port [20]. After the successfully implementation on CPEC, it will be a signal for the world that Pakistan is truly open for business and its inexpensive labor and fresh educated demographic is an alternative to India, Bangladesh and South East Asia etc [21].

However, CPEC grantees a permanent Chinese existence in Pakistan, it also assures Pakistan's stability. Chinese investment in Pakistan will make a strong China-Pakistan relationship which is a good thing for the stability of Pakistan and China will also not want a destabilized Pakistan due to its interests in the region [22]. CPEC from all counts will prove a game changer and will make China a backer in Pakistan's stability and security. It is a win-win situation for both countries. It will greatly expand the scope for the sustainable and stable development of China's economic development [23]. The fiber optic connectivity from Chinese boundary to Pakistan will be inaugurated. Through CPEC various wavelength data services can be extended to Pakistan from China, which can decrease the low bandwidth, poor connectivity and low speed problems of data transfer to Pakistan [24].

The Balochistan province is the largest province of Pakistan and its importance lies in the concentration of natural resources. Regardless of this, it has remained the underprivileged province in the country. The province is rich in natural resources, but the lesser and unskilled population because of the negligence of concerned authorities is a barrier in utilizing those resources. A low rate of urbanization and a high rate of unemployment are the reason behind low annual growth rate [25].

The development on Gwadar Port has been the most important development in recent years. The port would be a game changer for Balochistan, country, and region as well. Gwadar would be an economic hub and will contribute towards the progress of the whole province, subsequent in addressing the several economic and social problems of Balochistan and also would contribute towards reducing unemployment in the province. Micro and small-medium sized industries in the province would also contribute towards accomplishing greater benefits for the local residents [26]. There is a need to build a positive image of the CPEC through electronic and print media to remove misconceptions of the locals. It is important for the Pakistani government to make sure that people of Balochistan are fully included in the development and are also given a benefit [27].

\section{CONCLUSION AND RECOMMENDATION}

The Belt and Road Initiative is arguably one of the largest development plans in modern history. The Belt and Road Initiative refers to the Silk Road Economic Belt and 21st Century Maritime Silk Road, a significant development strategy launched by the Chinese government with the intention of promoting economic co-operation among countries along the proposed Belt and Road routes. The
Initiative has been designed to enhance the orderly free-flow of economic factors and the efficient allocation of resources. It is also intended to further market integration and create a regional economic co-operation framework of benefit to all. The main aim is connectivity and corporation of the People's Republic of China with Eurasia, Middle East, and Africa via Central South East Asia. BRI is a regional connectivity approach that consists of 68 countries and six economic corridors, among them CPEC is a mega project; CPEC is a very Critical Infrastructure corridor for both China and Pakistan. The corridor is mutually beneficial developments which fulfill the goals of both countries. For China, it offers an alternate route to import Energy and find new markets for its goods to the Middle East and Africa. For Pakistan, it supports to counter Indian influence in the region and connect the Eurasian region with South Asia and provide a much-needed base to start its economic growth. CPEC will help build a robust and stable economy in Pakistan and will create a significant opportunity for Pakistan to revive its industry and advance its economic interests. CPEC is a game changer project which will lift millions of Pakistanis out of poverty and misery. The project includes the construction of the textile garment, industrial projects, construction of dams, development of the information and communication technology, the installation of nuclear reactors and creating networks of road, a railway line which will generate employment and people will also take ownership of these projects. Fully equipped hospitals, technical training institutes, water supply and distribution in undeveloped areas will also improve the quality of life of people.

Same projects and activities should carry on time to time between China and Pakistan for the more economic improvement and development of both countries. These kinds of the plan will be supportive in alleviating the poverty and will generate more opportunities for employment; additionally, these kinds of projects would be very accommodating in the country's economy and development. Focusing on the successful implementation of projects and the development of an effective corridor will lead to cross-cultural and people-topeople contact.

\section{REFERENCES}

[1] Quora, What is One Belt, One Road in China? QUORA. Available at: https://www.quora.com/What-is-One-Belt-One-Road-in-China.June 2017.

[2] Dusitthani, What is One Belt, One Road in China? Dusitthani Sri Lanka. Available at: https://dusitthanisrilanka.com/2017/10/09/what-is-one-beltone-road-china/. October 2017.

[3] S. Troy, A. Ahearn, and F. McConnell, "Central Asian 'characteristics' on China's new Silk Road: The role of landscape and the politics of infrastructure," Land 6, vol. 55(3), 2017.

[4] A. Rumi, “'One Belt, One Road,' China's New Global Strategy,” Journal of Contemporary East Asia Studies, vol. 5(2), 2016, pp. 3-22.

[5] H.V. Pant, India challenges china's intentions on one Belt, One Road initiative. Yale Global oneline. Available at: https:/yaleglobal.yale.edu/content/india-challenges- chinasintentions-one-belt-one-road-initiative, June 2017.

[6] Z. Latif, M. Yang, Z. H. Pathan, and N. Jan, "Challenges and prospects of ICT and trade development in Asia," Human Systems Management, vol. 2017(36), pp. 211-219. 
[7] A. Muhammed, S. Asmi., F. Ali, M. Rahman., and M. Abbas., "ChinaPakistan Economic Corridor: In the context of "String of Pearl Strategy," International Journal of Business and Social Research, vol. 7(8), pp. 26-42, 2017.

[8] A. Waheed, L. Gang, and M. Raza, "China-Pakistan economic corridor: current developments and future prospect for regional integration," 2016.

[9] M.Z. Ispahani, Roads and Rivals: The Political Uses of Access in the Borderlands of Asia (First ed.). Cornell University Press.1989, ISBN: 978-0801422201, pp. 191.

[10] A. Ghulam, "China's strategic interests in Pakistan's port at Gwadar," In East Asia Forum, vol. 24, 2013.

[11] Dawn, Chinese premier in Pakistan, praises ties. DAWN. Available at; https://www.dawn.com/news/1012968. May 2013.

[12] S. Nihao, "Pakistan, China sign agreements,MoUs on Economic Corridor Plan, maritime cooperation," Available at: www.nihaosalam.com, May 2017.

[13] CNN, "Pakistan lands \$46 billion investment from China," CNN, April, 2015.

[14] M. Ahmed, chinese ship opens new trade route via Pakistan ports. "The associated press"Available https://www.bloomberg.com/news/articles/2016-11-13/chinese-shipopens-new-trade-route-via-pakistani-port, November 2016.

[15] A. Roychowdhury CPEC: the bumpy new trade route between china and Pakistan. New Dehli. Available at https://indianexpress.com/article/research/cpec-the-bumpy-new-traderoute-between-china-and-pakistan-4373203/, May 2017.

[16] U. Farooque, China-Pakistan Economic Corridor and Its Impact on Region. A Medium corporation. Available at: https://medium.com/supply-chain-hubspot/china-pakistan- economiccorridor-and-its-impact-on-region-b18b2aa01cc4. November 2016.

[17] Chinadaily, Backgrounder: China- Pakistan Economic Corridor. China Daily. Available http://www.chinadaily.com.cn/world/2015xivisitpse/201504/22/content_20503693.htm, April 2015.
[18] A. Malik N. Energy crisis in Pakistan. Naval Postgraduate School Monterey United States, 2015.

[19] B. K. Manzoor and A.A. Butt, "Impact of CPEC on Regional and ExtraRegional Actors," The Journal of Political Science vol. 3, pp. 23, 2015.

[20] A. Massarrat and A. Ashfaq, "CPEC: Challenges and opportunities for Pakistan," Journal of Pakistan Vision 16, vol. 2, pp. 142-169, 2015.

[21] R. Muhammad Ahsan, "Global Perspective of CPEC Regarding Economic Integration and Trade Openness," 2017.

[22] G. Yamada, Is China's Belt and Road working? A progress report from eight countries. Asian Review, available at: https://asia.nikkei.com/Spotlight/Cover- Story/Is-China-s-Beltand-Road-working-A-progress-report-from-eight-countries, March 2018.

[23] CSIS, Pakistan's Gwadar Port: A New Naval Base in China's String of Pearls in the Indo-Pacific. Centre for Strategic \& International Studies. Available at: https://www.csis.org/analysis/pakistansgwadar-port-new-naval-base-chinas-string- pearls-indo-pacific, April 2018.

[24] Z. Latif, Z. Jianqiu, R. Ullah, Z. H. Pathan, and S. Latif, “Application of optical frequency comb in high-capacity long distance optical communication for China-Pakistan economic corridor," Journal of Optical Communications 38, vol. 3, pp. 331-340, 2017.

[25] B. Mansoor Ahmed and A. Tanık, "Development of an integrated watershed management strategy for resource conservation in Balochistan Province of Pakistan," Desalination 226, vol. 1-3, pp. 38-46, 2008.

[26] H. Muzaffar, "China Pakistan Economic Corridor (CPEC): Challenges and the way forward," $\mathrm{PhD}$ diss., Monterey, California: Naval Postgraduate School, 2017.

[27] S. Jameel, The rise of Balochistan under CPEC. China- Pakistan Economic Corridor. Available at: http://www.cpecinfo.com/news/the-rise-of- balochistan-undercpec/NTIxOQ==. May 2018 . 